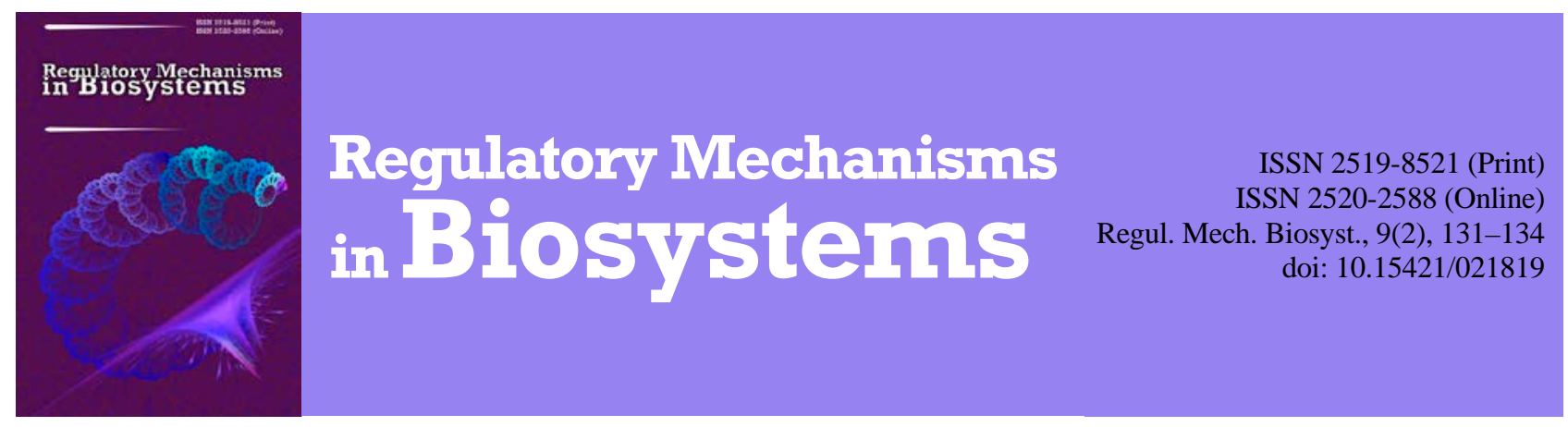

\title{
The effects of melatonin on the activity of the c-fos gene in the structures of the hypothalamic paraventricular nucleus under prolonged lighting
}

\author{
R. Y. Bulyk*, A. V. Abramov**, T. S. Bulyk*, M. I. Kryvchanska*, K. V. Vlasova* \\ *Bukovinian State Medical University, Chernivtsi, Ukraine \\ **Zaporizhzhya State Medical University, Zaporizhzhya, Ukraine
}

Article info

Received 24.02.2018

Received in revised form 14.03.2018

Accepted 17.03.2018

Bukovinian State Medical University, Theatralna sq., 2, Chernivtsi, 58002, Ukraine. Tel.: +38-037-255-37-54.

E-mail: bulyk@bsmu.edu.ua

Zaporizhzhya State Medical University, Mayakovsky ave., 26, Zaporizhzhya, 69035, Ukraine. Tel.: +38-061-224-63-91.

\begin{abstract}
Bulyk, R. Y., Abramov, A. V., Bulyk, T. S., Kryvchanska, M. I., \& Vlasova, K. V. (2018). The effects of melatonin on the activity of the c-fos gene in the structures of the hypothalamic paraventricular nucleus under prolonged lighting. Regulatory Mechanisms in Biosystems, 9(2), 131-134. doi:10.15421/021819
\end{abstract}

The effect of constant illumination as a stress factor on the state of the "early response" c-fos gene in the lateral magnocellular subnuclei of the paraventricular nucleus ( $\mathrm{mPVN}$ ) of the hypothalamus of rats at different time intervals (day and night) has been studied. To identify c-Fos in histological sections of the hypothalamus, a secondary (indirect) immunofluorescence method is used. Expression of the product of this gene, the c-Fos protein, in animals kept under normal conditions of alternation of illumination and darkness, shows a clear-cut circadian character. There was a significant decrease in the area of the immunopositive sites of structures at night by $19.4 \%$ compared to daytime measurements. The average values of the areas of such immunopositive subnuclei sites varied also in subgroups of rats under light stimulation conditions, in which samples of lmPVN were selected for study at 2 pm and 2 am, but the differences between groups did not reach the level of reliability. Under conditions of light stress, the c-Fos concentration index decreased by $29.4 \%$ during the day, and by $16.5 \%$ at night in relation to similar values in the intact group. In animals that were in the standard light mode, the c-Fos protein concentration index was significantly higher during the day than at night. In the intact group, the night value of the c-Fos concentration index averaged only $71.5 \%$ of the daily value. In rats subjected to constant illumination, the day and night values of the c-Fos concentration index did not differ reliably. To correct stress-induced changes in the activity of the "early response" c-fos gene in the rat hypothalamus, melatonin $(0.5 \mathrm{mg} / \mathrm{kg}$ body weight of the animal) was used. Injections of melatonin to rats exposed to constant illumination normalized the circadian rhythm of the area of the material immunoreactive to c-Fos, compared to the group of animals that did not receive melatonin. When using melatonin against the background of constant illumination, a sharp increase of the protein concentration in the lmPVN subnuclei of hypothalamus in daytime and less pronounced at night intervals was detected. Injections of melatonin to animals were also reflected in the daily dynamics of the index of c-Fos protein content in the ImPVN subnuclei under conditions of constant illumination. In the daytime observation period, the index was almost twice the experimental data on stressed animals without the introduction of the hormone, bringing it closer to normal. Prospects for further research in this sphere will allow us to better understand the place and role of subnuclei of paraventricular nuclei of the hypothalamus in the mechanisms of the formation of circadian rhythms of the rat brain.

Keywords: lateral magnocellular subnuclei; gene expression; c-Fos protein; photoperiod

\section{Introduction}

Within a wide range of environmental parameters, the photoperiod is the most reliable and stable synchronizing factor for homeothermic animals, including humans (Abreu \& Bragança, 2015; Lacoste et al., 2015; Arushanyan \& Shchetinin, 2016). Changes in the duration of the main timer, photoperiod, as a stress factor, desynchronize the rhythms of somatic and visceral functions (Houdek \& Sumová, 2014; Bedont \& Blackshaw, 2015; Wang et al., 2015), as well as coordination and modulation of the mechanisms of adaptation of the organism to the influence of various factors (Kobayashi et al., 2015; Kozaki et al., 2015).The pineal gland is actively involved in the stress response, being responsible for triggering a stress reaction and ensures adaptation of the body to changing environmental conditions (Zamorskiy et al., 2012; Erren \& Reiter, 2015).

One of the important links of the neuroendocrine system of the hypothalamus is the paraventricular nucleus (PVN) (Toshinai et al., 2014; Bains et al., 2015). These structures are the vegetative centers of coordination of functions and consist of a number of neuronal populations, subnuclei, which differ in structural-functional features and the nature of the neural connections with various parts of the nervous and neuroendocrine systems (Miklos et al., 2014; Bedont et al., 2015). Disruptions of the light regime (prolonged illumination, constant darkness) cause immediate changes in the expression of the c-fos gene in the PVN. The increase of its expression intensifies the synthesis of the corresponding immunospecific protein, c-Fos (Tymofii et al., 2015). This peptide participates in the mechanisms of synchronization of this activity with external cyclic influences, including circadian ones, associated with alternation of light and darkness (Reiter et al., 2014; Robinson \& Reddy, 2014).

When studying stress reactions and the action of stress-limiting factors (in particular, the hormone of the pineal gland, melatonin), studies of these subpopulations of neurons of the hypothalamus, PVN, are especially important. It is of interest to define the influence of the light stressor on the state of these subnuclei of PVN. It is important to study the changes in morphofunctional activity and the level of 
expression of the c-fos early-response gene in structures, and also to analyze the possibilities of increasing the adaptation of neurosecretory cells to the damaging effect of constant illumination as a stress factor. At the same time, the information on the effect of melatonin on the activity of these subpopulations of neurons of the hypothalamic PVN under different illumination conditions remains relatively limited.

The aim of the study was to evaluate the effect of constant illumination on the state of the early functional activity gene, c-fos, in the lateral magnocellular subnuclei of the paraventricular nucleus (ImPVN) of the rat hypothalamus at different time intervals and to analyze the change in the activity of this gene when melatonin is applied against the background of the light stressor.

\section{Material and methods}

Experiments were carried out on 48 mature male outbred white rats weighing $0.15-0.18 \mathrm{~kg}$. The animals were kept in standard animal facility conditions at a constant temperature and humidity and free access to water and food. The experimental rats were divided into four groups, each of which, in turn, consisted of two subgroups (six animals each).

The animals of the first group (intact) were kept for seven days in the conditions of the usual light regime (light-dark for 12 hours, illumination from 8 am to $8 \mathrm{pm}$ with fluorescent lamps, the illumination level in cages with animals was 500 lux). Rats of the second group were kept for seven days in conditions of constant illumination of similar intensity (induction of the hypofunction of the pineal gland). The animals of No. 3 series (control) were under the same experimental conditions as the rats of No. 1 series, but $1.0 \mathrm{ml}$ of the solvent $(0.9 \%$ ethanol solution in normal saline) was injected intraperitoneally daily at 19.00. The animals of series 4 were under experimental conditions, as were the rats of series 2 . Melatonin was injected intraperitoneally at 19.00 (Sigma, USA, purification rate - 99.5\%) at a dose of $0.5 \mathrm{mg} / \mathrm{kg}$, in $1.0 \mathrm{ml}$ of solvent ( $0.9 \%$ solution of ethanol in normal saline).

On the eighth day at $2 \mathrm{pm}$ and 2 am the animals were taken out of the experiment, and subjected to instant decapitation under Nembutal anesthesia ( $40.0 \mathrm{mg} / \mathrm{kg}$, ip). The animal's brain was immediately withdrawn and placed in a $10 \%$ phosphate-buffered formalin solution $(0.1 \mathrm{~m}$, $\mathrm{pH} 7.2$ ) for 20 hours at room temperature. After a standard procedure of dehydration and impregnation with chloroform and paraffin, the samples were poured into paraffin. All stages of the experiment were carried out in compliance with the basic requirements of the European Convention on Humane Treatment of Animals.

To identify c-Fos, a secondary (indirect) immunofluorescence method was used in the histological sections of the hypothalamus. Sections of $14 \mu \mathrm{m}$ in thickness were first dewaxed in xylene, then rehydrated in ethanol solutions of six descending concentrations (100-40\%) and washed three times for $10 \mathrm{~min}$ in phosphate buffer (0.1 m, pH 7.2).

As primary antibodies, rabbit polyclonal antibodies (immunoglobulin-IGG) to c-Fos ("Sigma-Aldrich", USA) were used. First, the sections were incubated for 45 minutes at $37^{\circ} \mathrm{C}$ in $0.3 \%$ Triton X-100 ("Sigma-Aldrich", USA) on $0.1 \mathrm{~m}$ phosphate buffer (pH 7.2) with the addition of $1 \%$ goat serum. Then, primary antibodies to c-Fos (1:1000) were applied to successive serial sections and incubated for 24 hours in a humid box at a reduced temperature $\left(4^{\circ} \mathrm{C}\right)$. After washing the excess primary antibodies in $0.1 \mathrm{M}$ phosphate buffer, the sections were incubated for $60 \mathrm{~min}$ at $37^{\circ} \mathrm{C}$ with secondary antibodies at $1: 200$ dilution. As secondary antibodies, goat gamma globulin was used which is a rabbit globulin antibody conjugated with fluorescein isothiocyanate (FITC, "Sigma-Aldrich", USA). After incubation, the sections were washed with phosphate buffer $(0.1 \mathrm{~m})$ and placed in a mixture of glycerol and phosphate buffer $(9: 1)$ for further investigation by luminescence microscopy. Control of antibody binding specificity was carried out in a similar manner, except for the incubation step with the primary antibodies to c-Fos.

Identification of c-Fos in neurons of the hypothalamus and determination of the content of this protein was carried out using VIDAS386, the computer-aided digital image analysis system ("Kontron Elektronik", Germany) in the ultraviolet spectrum. To produce a fluorescent image, a high-viscous filter with excitation and emission bands of 370-
390 and 420-450 nm, respectively, and a specialized lens with a wide aperture were used. Images made by using COHU-4922, an 8-bit CCD camera ("COHU Inc.", USA) were introduced into a computer image analysis system VIDAS-386. In this case, the effect of "burnout" of the drug, associated with the gradual destruction of FITC molecules under the influence of prolonged ultraviolet irradiation, is impossible. The introduced immunofluorescence image was digitized on a densitometric scale with 256 shades of grey. Image analysis was carried out in an automatic mode using VIDAS-2.5, the application software package ("Kontron Elektronik", Germany). Areas of samples in which the fluorescence intensity significantly exceeded the background values (inherent in the so-called nonspecific fluorescence), were identified. The area of these sections and the total cross-sectional area of the subnuclei of the PVN neurons containing the immunopositive material were measured ( $\mathrm{Si}$ and $\mathrm{Sn}$, respectively, $\mu \mathrm{m}^{2}$ ). Taking into account the fluorescence intensity in the immunopositive areas and the fluorescence intensity of the background $\left(D_{i}\right.$ and $\left.D_{0}\right)$, the indices characterizing the concentration of c-Fos and the content of this protein in the nuclei of immunopositive cells were calculated: $K_{i}=\left|\lg \left(D_{i} / D_{0}\right)\right|$ and $C_{i}=K_{i} \cdot S_{i}$ (conventional units - c.u.), respectively. Since these indices are relative, rather than absolute values, we will further refer to them as indices of concentration and content of c-Fos in immunopositive cells.

The topographic affiliation of the immunopositive neurons to the individual structures of the hypothalamus was mapped according to the stereotactic atlas of the rat brain.

The obtained experimental data was processed using a package of applied and statistical program VIDAS-2.5 (Kontron Elektronik, Germany). For the samples of all indices, the mean, standard deviation and average error were calculated. Samples of immunopositive cells of $\operatorname{lmPVN}$, in which $S_{i}$ and $S_{n}$ were measured, and the values of $K_{i}$ and $C_{i}$ in various groups of experimental animals were calculated, consisted of 120-153 units.

In addition, we calculated the localization density of c-Fosimmunopositive neurons within the investigated sections of the given nucleus. For this, the number of such cells was preliminarily determined in several (four to seven for each animal) randomly chosen fields of vision, and the average number of similar neurons per $1 \mathrm{~mm}^{2}$ of the cut area was calculated. The normality verification of the distribution of samples was carried out using the Shapiro-Wilk criterion. Since the distribution of most samples was not normal, the probability of differences in the values in the research and control groups of animals was determined at a significance level of $\mathrm{P}=0.05$ according to the Wilcoxon-Mann-Whitney U-criterion.

\section{Results}

By identifying the product of the expression of the "early response" gene c-fos by the immunofluorescence method in the lateral mangocellular subnuclei of the paraventricular nucleus (ImPVN) of the hypothalamus of intact animals, a significant decrease in the area of immunopositive sites of the structures at night was detected by $19.4 \%$ $(\mathrm{P}<0.05)$ compared to daytime values. The mean values of the areas of such immunopositive subnuclei sites varied somewhat and in subgroups of rats that were under light stimulation conditions, in which lmPVN samples were taken for study at $2 \mathrm{pm}$ and $2 \mathrm{am}$, but the intergroup differences did not reach the level of probability (Table 1).

Averaged over the entire group (without taking into account the time of day), the cross-sectional area of the subnuclei neurons of $\operatorname{lmPVN}$ in the animals modeled for epiphyseal hypofunction was significantly higher than the corresponding values in the intact group. The circadian dynamics of variations in the cross-sectional area of subnuclei was also different. In intact rats, the area at 2 am was $11.1 \%$ less than at 2 pm. In a group of animals that were in constant light, the average crosssectional area of the subnuclei at night and day was almost the same. In the process of pairwise comparison of the corresponding values measured in different series at $2 \mathrm{pm}$, it was found that the area of the subnuclei in light-stressed rats almost coincides with what was observed under physiological conditions. Analyzing the values in the samples taken at night, with hypofunction of the pineal gland, the indices are significantly 
larger (by 9.3\%), in comparison with the intact group (Table 2). Simulation of epiphyseal hypofunction significantly influenced the concentration of c-Fos protein in subnuclei of neurons of ImPVN. Under conditions of light stress, the c-Fos concentration index decreased by $29.4 \%$ during the day, and by $16.5 \%$ at night in relation to similar values in the intact group. In animals under the conditions of the standard light regi- me, the index of protein concentration c-Fos during the day was significantly higher $(\mathrm{P}<0.01)$ than the analogous value at night. In the intact group, the night value of the c-Fos concentration index averaged only $71.5 \%$ of the daily value. In rats subjected to constant illumination, the day and night values of the c-Fos concentration index did not differ reliably (Table 1).

\section{Table 1}

Characterization of cFos-immunopositive neurons in the lateral magnocellular subnuclei of the paraventricular nucleus of the hypothalamus of rats' for different durations of the photoperiod and administration of melatonin $(x \pm S D, n=6)$

\begin{tabular}{|c|c|c|c|c|c|}
\hline Animals series & $\begin{array}{c}\text { Material } \\
\text { immunoreactive } \\
\text { to c-Fos, } \mu \mathrm{m}^{2}\end{array}$ & $\begin{array}{l}\text { c-Fos protein } \\
\text { concentration } \\
\text { in neuron, } \mathrm{U}_{\text {if }}\end{array}$ & $\begin{array}{l}\text { c-Fos protein } \\
\text { content } \\
\text { in neuron, } \mathrm{U}_{\text {if }}\end{array}$ & $\begin{array}{l}\text { Size of c-Fos-- } \\
\text { immunopositive } \\
\text { neurons, } \mathrm{mm}^{2}\end{array}$ & $\begin{array}{c}\text { Total content } \\
\text { of c-Fos protein in the } \\
\text { structure, } \mathrm{U}_{\mathrm{if}} / \mathrm{mm}^{2}\end{array}$ \\
\hline Intact, 2 pm & $130.9 \pm 24.3$ & $0.30 \pm 0.05$ & $44.4 \pm 12.5$ & $190 \pm 39$ & $8436 \pm 1731$ \\
\hline Intact, 2 am & $105.5 \pm 12.2^{*}$ & $0.24 \pm 0.03^{*}$ & $24.7 \pm 3.9^{*}$ & $204 \pm 27$ & $5029 \pm 665$ \\
\hline Constant illumination, 2 pm & $129.3 \pm 25.6$ & $0.23 \pm 0.05^{*}$ & $29.7 \pm 8.6^{*}$ & $127 \pm 23$ & $3775 \pm 684^{*}$ \\
\hline Constant illumination, 2 am & $124.3 \pm 18.8$ & $0.20 \pm 0.03^{*}$ & $23.4 \pm 3.4$ & $120 \pm 25^{*}$ & $2811 \pm 586^{*}$ \\
\hline Constant illumination + melatonin, 2 pm & $124.5 \pm 29.4$ & $0.47 \pm 0.05^{\#}$ & $57.1 \pm 13.7^{\#}$ & $120 \pm 22$ & $6854 \pm 1257^{\#}$ \\
\hline Constant illumination + melatonin, 2 am & $111.6 \pm 38.9$ & $0.28 \pm 0.03^{\# \cdot * *}$ & $31.0 \pm 10.5^{* *}$ & $132 \pm 12$ & $4087 \pm 372$ \\
\hline
\end{tabular}

Note: * - probable changes in the parameters of intact animals group of the same time interval at the level of $\mathrm{P}<0.05$; ** - regarding the parameters of the animals of the previous time interval within the series at the level $\mathrm{P}<0,05$; ${ }^{\#}-$ for animals exposed to constant illumination at a level of $\mathrm{P}<0.05$.

\section{Table 2}

Effect of light stress on the neuron area of the lateral magnocellular subnuclei of the paraventricular nucleus $(\mathrm{ImPVN})$ in rats $(\mathrm{x} \pm \mathrm{SD}, \mathrm{n}=6)$

\begin{tabular}{lc}
\hline \multicolumn{1}{c}{ Experimental animals series } & Neuron area, $\mu \mathrm{m}^{2}$ \\
\hline Intact, $2 \mathrm{pm}$ & $91.1 \pm 3.2$ \\
Intact, 2 am & $81.0 \pm 4.9^{* *}$ \\
Constant illumination, $2 \mathrm{pm}$ & $88.7 \pm 3.4$ \\
Constant illumination, $2 \mathrm{am}$ & $88.5 \pm 3.9^{*}$ \\
\hline
\end{tabular}

Notes: * - difference from intact animals group of the same time interval at the level $\mathrm{P}<0.05$; ** - difference from intact group animals of the previous time interval within the series at the level $\mathrm{P}<0.05$.

Under these experimental conditions, the index of the c-Fos protein content in the subnuclei of neurons of $\operatorname{lmPVN}$ in the intact group at 2 am was significantly less (by $44.5 \%, \mathrm{P}<0.01$ ) than in the day. In individuals under conditions of light stress, the daily index of the c-Fos content was $33.0 \%$ lower than that in the intact group, and the night value was close to the value in this comparison group. The diurnal dynamics of this parameter turned out to be similar, however, there was no significant difference between day and night levels in the series of light-stressed animals.

As to the integrated density of the material immunoreactive to cFos in $\operatorname{lmPVN}$ tissue, this parameter varied from 120 to 204 neurons per $1 \mathrm{~mm}^{2}$ of the cut-off area in the subgroups studied. Note that in the intact rats, large values of the localization density of c-Fos-positive neurons in ImPVN were observed at night, and in the group of animals under hyperillumination, the circadian dynamics of this index acquired the reverse character: the density was large in the afternoon. While determining the density of these neurons, we have not established intergroup differences in the experimental series (Table 1).

An important effect on the index of c-Fos integrated density in the ImPVN tissue of the hypothalamus was the changes in the concentration of this protein and the index of its content in the subnuclei of neurons. The index of c-Fos total protein density in rats exposed to light stimulation was $55.3 \%$ lower in the afternoon and $44.1 \%$ lower at night than the same value in the intact group.

Injections to rats under standard light conditions, of a solvent $(1.0 \mathrm{ml}$ of a $0.9 \%$ solution of ethanol in normal saline) for seven days, did not significantly change the characteristics of c-Fos-immunopositive neurons in the lmPVN of hypothalamus. Therefore, the experimental data obtained in the next stages of the study will be compared with the parameters of the activity of the "early response" c-fos gene activity and the product of its expression, the c-Fos protein of intact animals.

Injections of melatonin $(0.5 \mathrm{mg} / \mathrm{kg}$ body weight of the animal) to rats subjected to constant illumination normalized the circadian rhythm of the area of the material immunoreactive to c-Fos compared to the group of animals to which melatonin was not administered. When melatonin was used against a background of constant illumination, the hormone led to a sharp increase $(0.47 \pm 0.05$ Uif) of protein concentration in the $\mathrm{lmPVN}$ subnuclei of the hypothalamus in the daytime and less pronounced ( $0.28 \pm 0.03 \mathrm{Uif})$ at night. Injections of melatonin to animals were also reflected in the daily dynamics of the index of protein content of c-Fos in the ImPVN subnuclei under the conditions of hypofunction of the pineal gland. So, at $2 \mathrm{pm}$ the index almost twice exceeded the experimental data on stressed animals without the introduction of the hormone, bringing it closer to normal. In addition, it was significantly higher compared with that in sections taken at $2 \mathrm{am}$ (Table 1 ).

The injection of the hormone to animals with epiphyseal hypofunction restored the daily rhythm of the integrated density of the material immunoreactive to c-Fos, but at $2 \mathrm{pm}$ it caused a decrease (by 5.5\%), and at 2 am a moderate increase (by 10.0\%) compared to the stressed animals without correction. The calculation of the index of total density of c-Fos in the ImPVN subnuclei of the hypothalamus showed that during the weekly administration of melatonin in daytime, the indicator was $6854 \pm 1257 \mathrm{Uif} / \mathrm{mm}^{2}$, and at night $4087 \pm 372 \mathrm{Uif} / \mathrm{mm}^{2}$. Thus melatonin on a background of constant illumination restored indices both at $2 \mathrm{pm}$ and 2 am relative to these indices in intact animals (Table 1 ).

Taking into account the results of the daily expression of the c-fos gene of the early functional activity in the ImPVN of the hypothalamus, we note its probable growth in the daytime. In individuals under conditions of light stress, the daily index of the c-Fos content was 33.0\% lower, and at night it approached the control values of the recorded diurnal dynamics. Injections of melatonin ( $0.5 \mathrm{mg} / \mathrm{kg}$ body weight) to light-sensitive animals affected the diurnal dynamics of the index of cFos protein content in ImPVN subnuclei of the hypothalamus. In particular, at $2 \mathrm{pm}$ the index was approaching the norm. In addition, it was significantly higher in comparison with that in the sections taken at $2 \mathrm{am}$.

\section{Discussion}

The leading structure, the pacemaker of circadian periodicity in mammals, is the suprachiasmatic nucleus of the hypothalamus, and the role of the main neuroendocrine mediator in providing circadian periodicity is assigned to the pineal gland (epiphysis of the brain) (Zamorskiy et al., 2012; Abreu \& Bragança, 2015; Erren \& Reiter, 2015; Lacoste et al., 2015; Arushanyan \& Shchetinin, 2016). Through the retino-hypothalamic tract, the SCN receives information on the level of external illumination. Fluctuations of this level, perceived by the photoreceptors of the retina, are the main timer for the "biological clock" of the SCN (Robinson \& Reddy, 2014; Bedont \& Blackshaw, 2015; Wang et al., 2015). Paraventricular nuclei of the hypothalamus are also involved in the formation of the temporal organization of physiological functions. As is known, these structures have complex cellular organization and include magnocellular and parvicellular subnuclei, whose neurons differ not only in size and efferent innervation but also in the spectrum of synthesized neuropeptides (Flak et al., 2014; 
Fan et al., 2016; Franco et al., 2016, Chun et al., 2017). These features determine the important role of PVN not only in the endocrine regulation of the trophic functions of the adenohypophysis, but also in the realization of the neuroendocrine response of the body to stress of various genesis, including prolonged illumination (Daubert et al., 2014; Herman et al., 2016; Miyake et al., 2016; Ordyan et al., 2016).

Analysis of the data obtained in this study indicates a clear circadian character of the expression of the product of the "early response" gene of the c-fos, c-Fos protein in animals kept under normal conditions of alternation of illumination and darkness. Taking into account the results of the daily expression of the gene of the early functional activity of c-fos in the hypothalamus $\operatorname{lmPVN}$, its probable growth in the daytime should be noted. In animals exposed to light stress, the daily index of the c-Fos content was 33.0\% lower, and in the night time it was approaching the control values of the registered diurnal dynamics. Injections of melatonin ( $0.5 \mathrm{mg} / \mathrm{kg}$ of mass) to light-stressed animals reflected on the daily dynamics of the studied parameters, including the index of c-Fos protein content in the subnucleus of the hypothalamus $\mathrm{lmPVN}$. In particular, at 2 pm the index was approaching the norm. In addition, it was significantly higher and in comparison with that in the sections taken at $2 \mathrm{am}$.

Changes in the geometric dimensions of cells and intracellular organelles are probably a very important phenomenon, which has not yet attracted due attention. As for the changes in the size of the nuclei of neurons, the most likely common cause of this can be considered changes in the intensity of protein synthesis, that is, the intensity of expression of certain genes in the nucleus. Obviously, specific mechanisms of dependence of nuclear sizes on intranuclear processes will be the subject of special studies.

\section{Conclusion}

Expression of the product of the "early response" c-fos gene, c-Fos protein in animals kept under normal conditions of alternation of illumination and darkness, showed a clear circadian character. A significant decrease of $19.4 \%$ in the area of the immunopositive sites of structures was found at night compared to daytime measurements. In individuals under conditions of light stress, the daily index of the c-Fos content was $33.0 \%$ lower, and at night it approached the control values. Injections of melatonin ( $0.5 \mathrm{mg} / \mathrm{kg}$ body weight) to stress-sensitive animals were reflected at $2 \mathrm{pm}$ by exceeding the index of c-Fos protein content in the ImPVN subnuclei almost twice as compared to the experimental data on stressed animals without hormone administration. At the same time, the trend towards normalization of the circadian dynamics of the gene expression was revealed.

Prospects for further research in this area will allow us to better understand the place and role of the subnuclei of the paraventricular nucleus of the hypothalamus in the mechanisms of the formation of circadian rhythms of the mammals' brain.

\section{References}

Abreu, T., \& Bragança, M. (2015). The bipolarity of light and dark: A review on bipolar disorder and circadian cycles. Journal of Affective Disorders, 185, 219-229.

Arushanyan, E. B., \& Shchetinin, E. V. (2016). Melatonin kak universal'nyy modulyator lyubykh patologicheskikh protsessov [Melatonin as a universal modulator of any pathological processes]. Patologicheskaya Fiziologiya i Eksperimental'naya Terapiya, 60(1), 79-88 (in Russian).

Bains, J. S., Wamsteeker Cusulin, J. I., \& Inoue, W. (2015). Stress-related synaptic plasticity in the hypothalamus. Nature Reviews Neuroscience, 16(7), 377-388.

Bedont, J. L., \& Blackshaw, S. (2015). Constructing the suprachiasmatic nucleus: A watchmaker's perspective on the central clockworks. Frontiers in Systems Neuroscience, 9, 74.

Bedont, J. L., Newman, E. A., \& Blackshaw, S. (2015). Patterning, specification, and differentiation in the developing hypothalamus. Wiley Interdisciplinary Reviews. Developmental Biology, 4(5), 445-468.

Chun, L. E., Christensen, J., Woodruff, E. R., Morton, S. J., Hinds, L. R., \& Spencer, R. L. (2017). Adrenal-dependent and independent stress-induced Per1 mRNA in hypothalamic paraventricular nucleus and prefrontal cortex of male and female rats. Stress, 22, 1-15.
Daubert, D. L., Looney, B. M., Clifton, R. R., Cho, J. N., \& Scheuer, D. A. (2014). Elevated corticosterone in the dorsal hindbrain increases plasma norepinephrine and neuropeptide $\mathrm{Y}$, and recruits a vasopressin response to stress. American Journal of Physiology. Regulatory, Integrative and Comparative Physiology, 307(2), R212-224.

Erren, T. C., \& Reiter, R. J. (2015). Melatonin: A universal time messenger. Neuroendocrinology Letters, 36(3), 187-192.

Fan, S., Dakshinamoorthy, J., Kim, E. R., Xu, Y., Huang, C., \& Tong, Q. (2016). An indirect action contributes to c-fos induction in paraventricular hypothalamic nucleus by neuropeptide Y. Scientific Reports, 6, 19980.

Flak, J. N., Myers, B., Solomon, M. B., McKlveen, J. M., Krause, E. G., \& Herman, J. P. (2014). Role of paraventricular nucleus-projecting norepinephrine/epinephrine neurons in acute and chronic stress. European Journal of Neuroscience, 39(11), 1903-1911.

Franco, A. J., Chen, C., Scullen, T., Zsombok, A., Salahudeen, A. A., Di, S., Herman, J. P., \& Tasker, J. G. (2016). Sensitization of the hypothalamic-pituitary-adrenal axis in a male rat chronic stress model. Endocrinology, 157(6), 2346-2355.

Furlong, T. M., McDowall, L. M., Horiuchi, J., Polson, J. W., \& Dampney, R. A. (2014). The effect of air puff stress on c-Fos expression in rat hypothalamus and brainstem: Central circuitry mediating sympathoexcitation and baroreflex resetting. European Journal of Neuroscience, 39(9), 1429-1438.

Herman, J. P., McKlveen, J. M., Ghosal, S., Kopp, B., Wulsin, A., Makinson, R., Scheimann, J., \& Myers, B. (2016). Regulation of the hypothalamic-pituitaryadrenocortical stress response. Comprehensive Physiology, 6(2), 603-621.

Houdek, P., \& Sumová, A. (2014). In vivo initiation of clock gene expression rhythmicity in fetal rat suprachiasmatic nuclei. PLoS One, 9(9), e107360.

Inta, I., Bettendorf, M., \& Gass, P. (2016). Conserved hypothalamic c-fos activation pattern induced by the MGLU5 receptor antagonist MPEP during peripubertal development in mice. Pharmacopsychiatry, 49(4), 142-145.

Kobayashi, Y., Ye, Z., \& Hensch, T. K. (2015). Clock genes control cortical critical period timing. Neuron, 86(1), 264-275.

Kozaki, T., Kubokawa, A., Taketomi, R., \& Hatae, K. (2015). Effects of day-time exposure to different light intensities on light-induced melatonin suppression at night. Journal of Physiological Anthropology, 34(1), 27.

Lacoste, B., Angeloni, D., Dominguez-Lopez, S., Calderoni, S., Mauro, A., Fraschini, F, Descarries, L., \& Gobbi, G. (2015). Anatomical and cellular localization of melatonin MT1 and MT2 receptors in the adult rat brain. Journal of Pineal Research, 58(4), 397-417.

Miklos, Z., Flynn, F., \& Lessard, A. (2014). Stress-induced dendritic internalization and nuclear translocation of the neurokinin-3 (NK3) receptor in vasopressinergic profiles of the rat paraventricular nucleus of the hypothalamus. Brain Research, 1590, 31-44.

Miyake, H., Mori, D., Katayama, T., Fujiwara, S., Sato, Y., Azuma, K., \& Kubo, K. Y. (2016). Novel stress increases hypothalamic-pituitary-adrenal activity in mice with a raised bite. Archives of Oral Biology, 68, 55-60.

Ordyan, N. E., Pivina, S. G., Rakitskaya, V. V., \& Akulova, V. K. (2016). Harakteristika aktivnosti gipotalamo-gipofizamo-nadpochechnikovoj sistemy prenatal'no stressirovannyh samcov krys v jeksperimental'noj modeli depressii [Activity of hypothalamic-pituitary-adrenal axis of prenatally stressed male rats in experimental model of depression]. Zhurnal Evoliutsionnoi Biokhimii i Fiziologii, 52(1), 51-57 (in Russian).

Reiter, R. J., Tan, D. X., \& Galano, A. (2014). Melatonin: Exceeding expectations. Physiology (Bethesda), 29(5), 325-333.

Robinson, I., \& Reddy, A. (2014). Molecular mechanisms of the circadian clockwork in mammals. FEBS Letters, 588(15), 2477-2483.

Toshinai, K., Saito, T., Yamaguchi, H., Sasaki, K., Tsuchimochi, W., Minamino, N., Ueta, Y., \& Nakazato, M. (2014). Neuroendocrine regulatory peptide-1 and -2 (NERPs) inhibit the excitability of magnocellular neurosecretory cells in the hypothalamus. Brain Research, 1563, 52-60.

Tymofii, O. V., Bulyk, R. Y., \& Lomakina, Y. V. (2015). Efekty melatoninu na ekspresiiu hena c-Fos u neironakh medial'noho dribnoklitynnoho sub'iadra paraventrykuliamoho yadra hipotalamusa schuriv pry zminenomu fotoperiodi [Melatonin's effects on the c-fos gene expression in neurons of the medial small subnucleus of hypothalamus paraventricular nucleus of rats under altered light condition]. Svit Medytsyny ta Biolohii, 2(50), 187-191 (in Ukrainian).

Wang, J. L., Lim, A. S., Chiang, W. Y., Hsieh, W. H., Lo, M. T., Schneider, J. A., Buchman, A. S., Bennett, D. A., Hu, K., \& Saper, C. B. (2015). Suprachiasmatic neuron numbers and rest-activity circadian rhythms in older humans. Annals of Neurology, 78(2), 317-322.

Zamorskiy, I. I., Sopova, I. Y., \& Khavinson, V. K. (2012). Vliyanie melatonina i epitalamina na soderzhanie produktov belkovoy i lipidnoy peroksidatsii v kore bol'shikh polushariy i gippokampe mozga krys v usloviyakh ostroy gipoksii [Effects of melatonin and epithalamin on the content of protein and lipid peroxidation products in rat cortex and hippocampus under conditions of acute hypoxia]. Byulleten' Eksperimental'noy Biologii i Meditsiny, 154(7), 59-61 (in Russian). 